Bryn Mawr College

Scholarship, Research, and Creative Work at Bryn Mawr College

Classical and Near Eastern Archaeology Faculty

Research and Scholarship

Classical and Near Eastern Archaeology

1982

\title{
Excavations at Tsoungiza (Archaia Nemea) 1981
}

James C. Wright

Bryn Mawr College, jwright@brynmawr.edu

Let us know how access to this document benefits you.

Follow this and additional works at: http://repository.brynmawr.edu/arch_pubs

Part of the Classical Archaeology and Art History Commons, and the History of Art, Architecture, and Archaeology Commons

\section{Custom Citation}

Wright, James C. 1982. Excavations At Tsoungiza (Archaia Nemea) 1981. Hesperia 51:375-397.

This paper is posted at Scholarship, Research, and Creative Work at Bryn Mawr College. http://repository.brynmawr.edu/arch_pubs/32

For more information, please contact repository@brynmawr.edu. 


\section{EXGAVATIONS AT TSOUNGIZA (ARCHAIA NEMEA)}

1981

(Plates 89-92)

D URING May and June 1981, a brief excavation was conducted on the hill of Tsoungiza just west of the Sanctuary of Zeus at Nemea. The work was carried out by the author and assistants at the request of Professor Stephen G. Miller, Director of the Nemea Excavations. ${ }^{1}$ The investigation was spurred by the receipt from Professor George E. Mylonas of the notes and manuscript of the late Professor John P. Harland which form the unpublished results of his explorations of the hill in 1926 and 1927..$^{2}$ The aims of this summer's work were to examine the stratigraphy of the site by means of a deep sounding and to develop a technical strategy for the project, which included techniques of recovery and sampling, methods of study, classification and storage of the artifacts, and initial consideration of the topography of the locale. In this manner we hoped to assess the extent to which a large-scale project could or should be conducted, to establish a research design for such work, and to provide initial supplementary data for the eventual publication of the original excavation of over fifty years ago.

As this report will show, not all these desiderata were fulfilled: the sondage was frustrated by the happy discovery of a Middle Helladic floor deposit, and a lack of time prevented more than the most informal assessment of the topography of the area. Nonetheless, the results were rewarding enough to encourage further work. Experimentation with techniques was especially successful, and the well-equipped facilities of the Nemea Excavations much simplified curatorial activities and storage.

${ }^{1}$ I wish to thank Professor Miller for inviting me to undertake this project and for funding it. The facilities of the Nemea Excavation workrooms and the kind help of Professor Stella G. Miller and her assistant Patricia Felch much simplified study and conservation of the finds. Dr. Katerina DemakopoulouPapantoniou, Ephor of Antiquities for the Argolid-Corinthia, gave useful advice during the course of the work. George Papaioannou kindly supplied his chicken shed for installation of the water-sieving operation. Demetrios Niteros, foreman at Nemea, provided much useful assistance and advice. My wife, Mary Dabney, of Columbia University, supervised the work in the trench, and Francis De Mita of Haverford College assisted at every level of the work. Craig A. Mauzy, photographer of the Nemea Excavations, is to be thanked for the photographs. College.

My expenses were largely supported by a grant from the Madge Miller Fund of Bryn Mawr

I wish to thank Professors Stephen G. Miller and Jeremy Rutter, Dr. Tamara Stech, and Mary Dabney for reading a draft of this report and making numerous helpful suggestions which I incorporated in the text.

${ }^{2}$ I wish to thank Professor Mylonas for entrusting me with Professor Harland's manuscript and the responsibility of its publication. For early reports of these researches, see C. W. Blegen, "The American Excavations at Nemea," Art and Archaeology 21, April 1925, pp. 183-184; "The December Excavations at Nemea," Art and Archaeology 22, October 1926, pp. 133-139; "Excavations at Nemea, 1926," AJA 31, 1927, pp. 436-440; J. P. Harland, "The Excavations of Tsoungiza, the Prehistoric Site of Nemea," AJA 32, 1928, p. 63. 


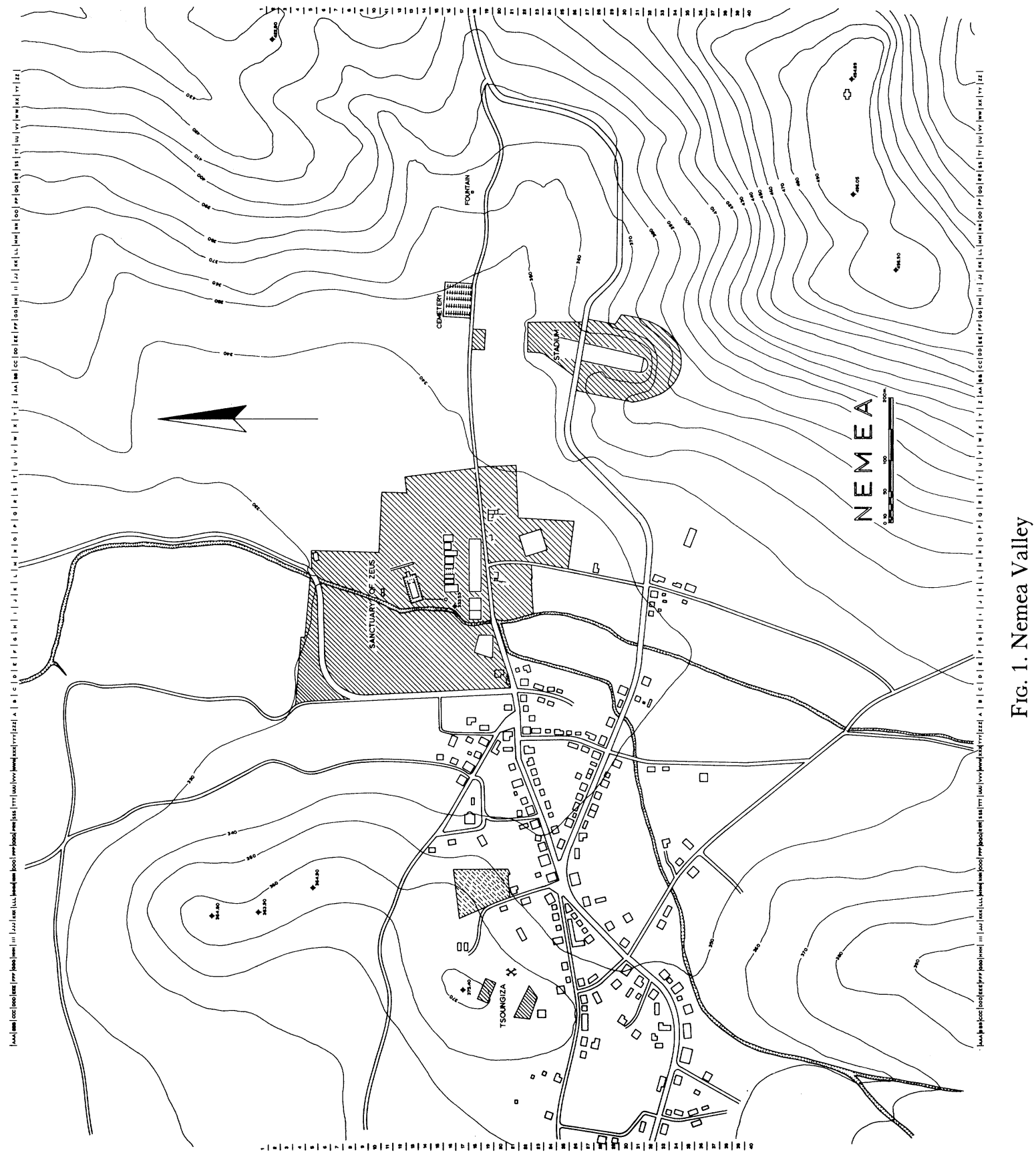




\section{Previous Excavations}

The history of excavation at Tsoungiza has not, so far, been fortunate. The site which in the 1920's divulged the earliest skeletal remains then known from Greece (Early Neolithic) and disclosed abundant Early through Late Helladic occupation still remains unknown and virtually unexplored. ${ }^{3}$ The attention of Carl Blegen was drawn to Tsoungiza while he was working in the Sanctuary of Zeus. He had recently excavated the prehistoric settlement of Zygouries in the adjacent valley of Kleonai, and the investigation of Tsoungiza was a natural extension of his interests. Trial trenches were opened on the crown of the hill in 1924. Of these only the briefest of reports was ever made. ${ }^{4}$ Subsequent work by Blegen, who was occupied with the publication of Zygouries and his duties as Assistant, and then Acting, Director of the School, was limited to the Neolithic "cave", the publication of which has only recently appeared thanks to the efforts of the late Professor J. L. Caskey. ${ }^{5}$ In 1926 Blegen turned the exploration of the site over to J. P. Harland who conducted an intensive excavation of the Bronze Age levels on the crest of the hill and in subsequent years prepared the results for publication. Unfortunately this work languished, and his death left it uncompleted. Since then the present Nemea project under the sponsorship of the University of California at Berkeley has begun; and in 1974, 1975, 1979, and now in 1982, salvage work, including the purchase and expropriation of two plots of land, has been conducted by Professor Miller to save the settlement remains on the hill. ${ }^{6}$ The results of these rescue efforts made apparent the need for a renewed and focused examination of the site. Recent activities in the area of the adjacent western valley near Aidone by the Ephoreia of Antiquities for the Argolid and the Corinthia have disclosed rich Mycenaean tombs which underline the importance of this hinterland of the Corinthia during the Bronze Age and emphasize the need for survey and excavation.

\section{Geographical Setting}

The Sanctuary of Zeus and the site of Tsoungiza (as well as the modern and 19thcentury villages of Archaia Nemea and Koutsomodi, respectively) are located at the head or southern end of the small Nemea Valley through which flows a small river. This end of the valley is enclosed by a ring of low hills which form a water catchment that supplies the river. The hills continue to the north flanking the valley on either side. Less than two kilometers from the head of the valley it narrows, and the river cuts deeply into the valley floor and runs down to the Corinthian Gulf.

Philippson gives a general description of the landscape around the valley. ${ }^{7}$ It is composed of Neogene marls except at its southern end. There the high hills that flank the basin

${ }^{3}$ The skeletal remains are referred to in the report of L. Angel, "Neolithic Ancestors of the Greeks," $A J A 49,1945$, pp. 252-260, and published by C. M. Fürst, "Über einem neolithischen Schädel aus Arkadien," Lunds Universitets Arsskrift, n.f. Avd. 2, Bd. 28, Nr. 13, 1932, the latter of which I have not seen.

${ }^{4}$ See footnote 2 above.

${ }^{5}$ C. W. Blegen, "Neolithic Remains at Nemea," Hesperia 44, 1975, pp. 251-279.

${ }^{6}$ S. G. Miller, "Excavations at Nemea," Hesperia 44, 1975, pp. 150-152; Hesperia 45, 1976, pp. 174-177; Hesperia 49, 1980, pp. 203-205.

${ }^{7}$ A. Philippson, Die griechischen Landschaften, III, i, Der Peloponnes, E. Kirsten, ed., Frankfurt am Main 1959, pp. 90-92. 
of the valley, Evangelistria above the stadium and Ntaouli at the west, are composed of Tripolitsa limestone. ${ }^{8}$ The upper valley floor is filled with recent alluvium, which can be as deep as about $2.5 \mathrm{~m}$. in some areas and is dated after the 6th century after Christ. ${ }^{9}$ This alluvium covers the Sanctuary of Zeus, decreasing in thickness to the north. It overlies at least one stream bed that originally flowed down from the east to the Nemea river. ${ }^{10}$ The sum of this evidence compares favorably with the Younger Fill identified throughout the Mediterranean by Vita-Finzi and more locally in the Argolid by Bintliff. ${ }^{11}$ Thus the modern course of the river is a relatively recent phenomenon cutting through this fill. (The implications of this occurrence for the recovery of the original form of the valley floor in prehistoric times will be discussed later.)

As has been observed by Bintliff, ${ }^{12}$ the deposits of Younger Fill in Greece are extremely fertile and form distinct zones of agriculture. The Nemea Valley is no exception. The valley bottom is extensively exploited and supports a wide variety of crops: wheat and barley, fruit trees, and vineyards. Of these the vineyards are now dominant, especially since the importation of a strain of hardy California grape in the last decade or so. At the boundaries of the alluvium the Neogene marl rises up forming the slopesides. These hill soils support cereal and olive cultivation. Local rainfall provides adequate water through May' and abundant aquifers are located atop the marl under the valley floor at depths from 8 to 12 meters. Numerous springs are found along the slopes on either side of the valley. The higher slopes of the hills flanking the valley are a maquis cut through by occasional ravines with stands of cypress. This thick cover offers little pasturage, which is notably lacking in the region.

The valley is flanked by adjacent and similar but broader valleys. To the east is that of the interior of the Corinthia containing the settlements of Archaia Kleonai (modern Kondostavro or Kondostavlo ${ }^{13}$ ) and Agios Vasilios where lies prehistoric Zygouries. To the immediate west lies modern New Nemea with the near-by ancient site of Phlious. These all form part of the foothills of the range of Mount Kyllene (modern Ziria).

Easily accessible passes at east and west of the head of the Nemea Valley connect it with these neighbors. In fact, the valley is situated along or close to natural routes of access to the northeastern Peloponnesos. Thus its proximity to the Tretos pass places it along a strategic passage from the Argolic plain to the Corinthia. The Nemea Valley also sits astride the easiest passage from the Argolid to the southern coastal plain of the Gulf of Corinth. ${ }^{14}$

${ }^{8}$ Ibid., fig. 6.

${ }^{9}$ S. G. Miller, "Excavations at Nemea, 1978," Hesperia 48, 1979, pp. 90-92; Hesperia 49, 1980, p. 192.

${ }^{10} \mathrm{Ibid}$. and idem, Hesperia 44, 1975, pp. 167-169.

${ }^{11}$ C. Vita-Finzi, The Mediterranean Valleys, Cambridge 1969, and J. Bintliff, Natural Environment and Human Settlement in Prehistoric Greece, BAR Suppl. series, 28, i, 1977, pp. 35-53, passim. The identification of the causes and effects of this fill are, however, controversial. See the summary discussion by D. Davidson and C. Tasker in An Island Polity: The Archaeology of Exploitation in Melos, C. Renfrew and M. Wagstaff, edd., New York 1982, pp. 92-93.

${ }^{12}$ Op. cit., pp. 87-108, 274-345.

${ }^{13}$ For this alternate toponym see C. Grigouras et cie. Maison cartographique, Athens, n.d., map: $\Pi \Delta$ "KOPINOOE".

${ }^{14}$ Philippson, op. cit. (footnote 7 above), p. 92; thus the Nemea river was an area of strife between 
Likewise, entrance to the valley provides access to the northern extension of the Arcadian mountains at the west.

The hill of Tsoungiza is a serpentine ridge along the western side of the valley extending north from the edge of the village of Heraklion (Archaia Nemea). For over 600 meters the ridge runs northward, covered with olives for the most part except at its southern end which is partly fallow and partly given over to vineyards (Fig. 1). There a knob of the ridge about 375 meters above sea level forms the area of Bronze Age occupation, while along its slopes to east and south are traces of Early Neolithic and intermittent Bronze Age remains. Although future examination will better reveal the surface geology of the site, it appears to be an eroded outlier of the lower slope of Ntaouli to the southwest and Prophitis Elias to the west, both of which like Tsoungiza are largely composed of Neogene marl. The topsoil of the hilltop is primarily occupation debris; along the slopes the white marl is predominant.

\section{Present Excavations}

\section{A. Excavation Procedures}

The recent excavations have been located directly south of the crown of the hill (Figs. 1, 2), primarily within the 20-meter-square grids EEE19 and FFF19. The excavation of 1981 occupied the $5 \times 5 \mathrm{~m}$. square at the southeastern corner of EEE19, designated $\mathrm{EEE} / 16,20-19 / 16,20$. The trench was selected to fit into the grid yet to take advantage of the increasing depth of fill observable at the southeastern corner of the plot of land available for excavation.

The original aim of the work was to open two trenches, one on the hill and one in the Sanctuary, in order to explore the prehistoric deposits identified in the Sanctuary in 1979 in grids F-G-18-19, the area tentatively identified as a heroon. ${ }^{15}$ Because of heavy winter rains this latter work had to be deferred, and our total attention was given to the work on the hill. Although we intended only to test the stratigraphy of the hill, the trench was laid out with $1 \times 1 \mathrm{~m}$. grid squares on the hypothesis that spatial isolation of all archaeological remains would be a priority of future work and necessary for functional interpretation at the settlement. ${ }^{16}$ The intention was to recover material separately for each grid square while assigning it to a stratigraphic unit. Thus there are a total of 25 spatial units within the trench, each designated by a grid number, e.g. EEE/16-19/17, and assigned a stratigraphic (bucket or locus) number, e.g. EEE/16-19/17 no. 1 and EEE/16-19/18 no. 1. For quick stratigraphic reference these can be referred to as "bucket \#1", while the location is supplied by the grid-square designations. At the suggestion of Mary Dabney, supervisor of the trench, this grid was employed in a simulated surface survey of the area of the trench. After removal of the vines and weeds in the area to be excavated, the workmen turned over the soil

Sikyon and Corinth (Strabo, viIr.6.25; Livy, xxxiI.15.1). See W. K. Pritchett, Studies in Ancient Greek Topography, II, Battlefields, University of California Publications: Classical Studies IV, Berkeley 1969, chaps. VI and VIII.

${ }^{15}$ S. G. Miller, "Excavations at Nemea, 1980," Hesperia 50, 1981, pp. 60-65.

${ }^{16}$ See L. Binford, "A Consideration of Archaeological Research Design," American Antiquity 29, 1964, p. 434; J. N. Hill, "Prehistoric Social Organization in the American Southwest: Theory and Method," Reconstructing Prehistoric Pueblo Societies, W. H. Longacre, ed., Albuquerque, New Mexico 1970, pp. 11-58. 


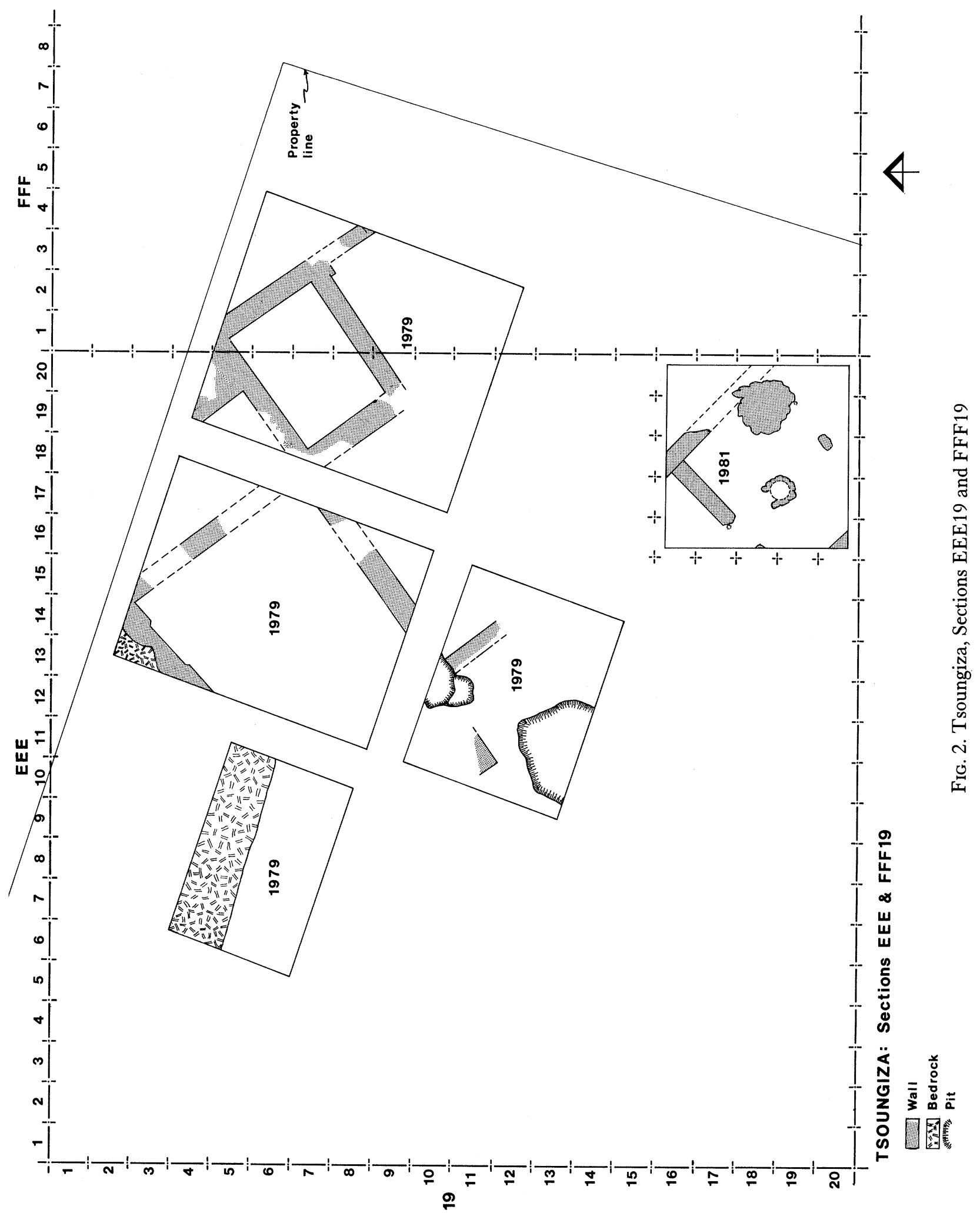


with large picks to simulate plowing. The surface material was then gathered by grid square (Pl. 89:a). As excavation continues this process will be carried out for every trench and will provide a useful base for comparing the surface material with preserved remains and for establishing the drift of material remains around the hillside. An accurate base for future comparison will also be established for other grid-surveyed sites in the region. ${ }^{17}$

Within the trench, one grid square, EEE/18-19/17, was selected as a control column. All the material removed from this grid square was processed through a sample splitter which provided an accurate sample of one quarter of the excavated stone and soil for water sieving and other analyses. The remaining three quarters were dry sieved through a 1centimeter-mesh screen. Use of this screen was standard procedure for all excavated material from the trench. A shaker sieve was not employed because it is too destructive of organic and fragile artifactual remains. Rather, one shovelfull of soil at a time was taken directly from the trench and sorted through a screen box placed over a wheelbarrow. This procedure was efficient and will be continued in the future.

The sample splitter mentioned above was homemade, the variety available from geological warehouses being too expensive for present purposes. ${ }^{18}$ The photograph (Pl. 89:a) shows it set up and illustrates its design and construction. ${ }^{19}$ The principle behind the device is to create a measurable and representative sample at the site rather than after processing, thus reducing man hours involved in sieving and sorting. ${ }^{20}$ Soil introduced into the upper cone of the splitter passes through a chicken-wire screen $(3.5 \times 3.5 \mathrm{~cm}$.) to sort out the stones and roots that would block the lower spout of the cone. As the soil passes through the cone it is mixed (a pipe used as a stirrer helped at this stage) and then flows through a cylinder with a $2.5-\mathrm{cm}$. radius. The cylinder is fixed over the center point of a lower, inverted, unperforated cone of sheet metal. The constant flow over this cone produced an even distribution of soil around its circumference; the soil fell into four metal tins placed under the four quadrants of the cone. Any one of these tins contained a $25 \%$ sample of the soil. The device, nicknamed the "Space Shuttle Columbia" by the village workers, worked tolerably well. Improvements can be made by lengthening the dispersal cone to insure an even and constant flow or by devising a more accurate splitter employing baffles. ${ }^{21}$ As a timesaver it was invaluable. One person was able to handle all the water sieving and spreading of the sieved fraction, even when after the discovery of a floor deposit we were sieving every part of the trench. Furthermore, the splitter's use reduced by three quarters the amount of watersieved material, which saved space required for drying and sorting it.

${ }^{17}$ Experiments of this nature have been carried out at numerous sites with varying degrees of success. See, for example, J. Ford and G. Willey, "Surface Survey of the Viru Valley, Peru," Anthropological Papers of the American Museum of Natural History, 43, i, 1949, pp. 34-37; C. Redman and P. J. Watson, "Systematic, Intensive Surface Collection," American Antiquity 35, 1970, pp. 279-291.

${ }^{18}$ Cf. Gilson Company, P.O. Box 677, Worthington, Ohio, 43085, Gatalogue 1981, p. 30, "SP-1" (\$346), “SP-2" (\$213).

19 Ours was made from $12 \mathrm{~m}$. of $7 \times 7 \mathrm{~cm}$. fir, 2 sq. m. of sheet metal, and rivets and cost about $\$ 40$.

${ }^{20}$ Problems of sampling in archaeology are discussed by Binford (op. cit. [footnote 16 above], pp. 425-441); James A. Brown, "Deep-site Excavation Strategy as a Sampling Problem," and J. Jefferson Reid et al., "Archaeological Considerations of Intrasite Sampling," in Sampling in Archaeology, James W. Mueller, ed., Tuscon, Arizona 1975, pp. 155-169 and 209-225, respectively.

${ }^{21}$ See the standard geological splitters referred to above, footnote 18. 


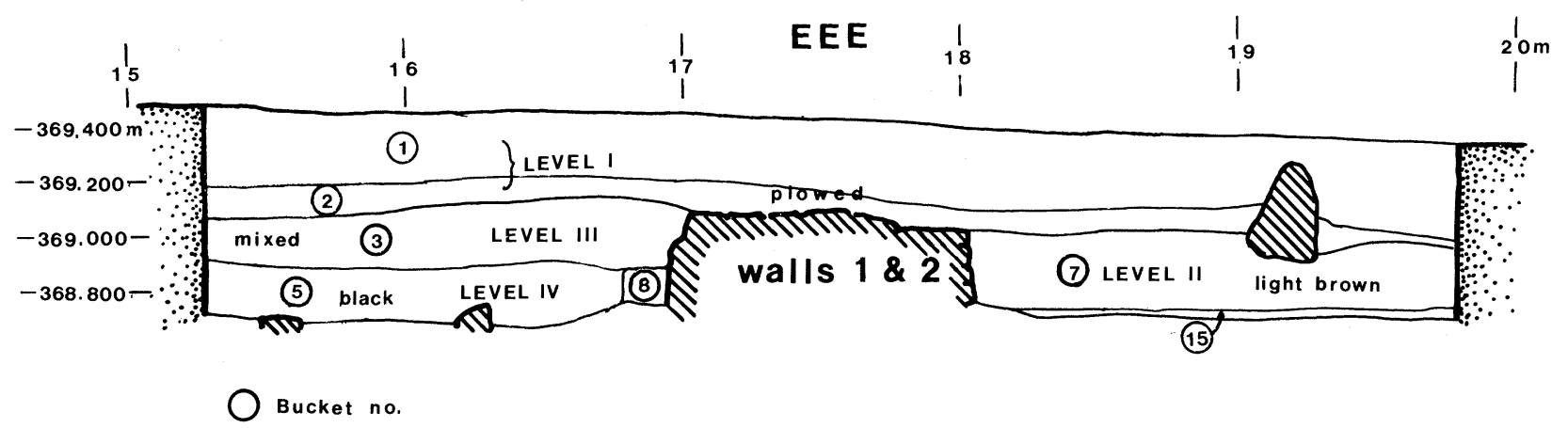

FIG. 3. Scarp section looking north

The wet sieve was a water-separation device of the type developed by D. French at Ashvan and successfully employed at Franchthi and, recently, at Corinth, whence we borrowed ours. ${ }^{22}$ Some modifications were made in the normal arrangements of the sieves. ${ }^{23}$ Two screens, one fitted within the other, were installed in the flotation chamber instead of the normal one. The upper was of 1-centimeter mesh and the lower of 5-millimeter mesh. Both were submerged. The effect of using two screens was to create two heavy fractions; the upper or larger-size one was easily hand sorted while the lower contained only granules of stone and archaeological material. This system was necessitated by the decision not to dry sieve the sample before water sieving and was developed after work had commenced. The light, floated fraction was caught in a very fine flour sieve with $1 / 2$-millimeter mesh equal to a \#35 standard geological sieve and much cheaper ( $\$ 3$ as opposed to $\$ 37$ per sieve). The fractions of sieved material were dried on newspaper laid on hothouse plastic tarp which had been laid over the floor of the chicken shed housing the operation. Sorting was done in this shaded shed as well. Material was sorted into the following categories: seed and root, charcoal, shell, bone, stone, and stored in "zip-loc" plastic bags after thorough drying. As one might imagine, most of the fraction was not sorted owing to a lack of personnel.

The result of these attentions to recovery was an increased recognition by the workers in the trench of the value of hand recovery. In contrast to frequent past experiences where it proved difficult to convince workers of the need to work slowly and systematically and to recover remains consistently, the experience of this summer was gratifying, and the difference in orientation was obvious: many whole seeds, much charcoal, and virtually all sherds and stone tools were recovered by hand, an observation confirmed by the small number of

${ }^{22}$ S. Diamant, "A Short History of Archaeological Sieving at Franchthi Cave, Greece," JFA 6, 1979, pp. 203-217; C. K. Williams, II, "Corinth 1975: Forum Southwest," Hesperia 45, 1976, p. 100, note 3. I wish to thank Mr. Williams, Director of the Corinth Excavations, for the loan of the water sieve belonging to the Corinth excavations.

${ }^{23}$ See D. French, "An Experiment in Water-Sieving," AnatSt 20, 1971, pp. 59-64; Diamant, op. cit., pp. 210-211; P. J. Watson, "In Pursuit of Economic Subsistence: A Comparative Account of Some Contemporary Flotation Techniques," Mid-Continental Journal of Archaeology 1, 1976, pp. 77-100, which gives an excellent account of the history of water sieving and offers detailed plans of a simple and efficient flotation device which provided inspiration for our modifications. 


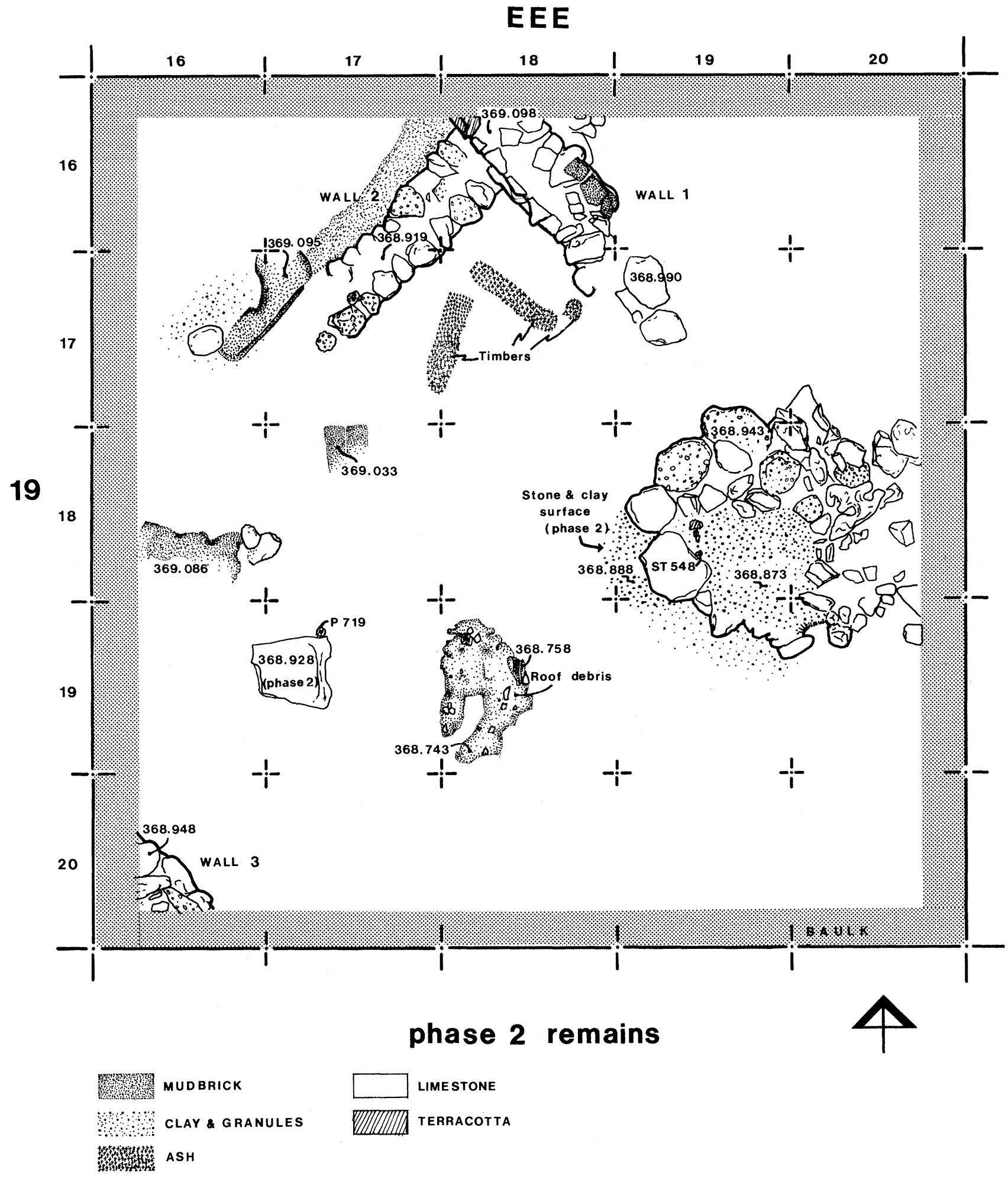

FIG. 4. Tsoungiza, destruction debris and Phase 2 remains 
these items from the sieved material, which contained mostly small $(2-3 \mathrm{~mm}$.) seed, charcoal, and shell.

\section{B. Description of Excavation}

The 5-meter-square trench selected for excavation in grid EEE19 had been plowed in recent years, and the top layer of soil after removal of the vines was disturbed to depths from 25 to $50 \mathrm{~cm}$. Much of this disturbance contained mixed pottery: periods represented were Early Neolithic, Early Helladic II and III, Middle Helladic, and Late Helladic I-III (level I, Fig. 3). Beneath this surface no uniform level appeared although clear indications were recognized of a SE wall 1 (Fig. 4) and, probably, wall 2 at right angles to it. A stone- and clay-covered surface appeared in grid EEE/19-19/18 and a tumble of stones north of it in $\mathrm{EEE} / 19,20-19 / 16,17$. Also probably connected with this phase was a large stone base in grid EEE/17-19/19 (Fig. 4). These features are all at comparable elevations ( + 368.873$368.926 \mathrm{~m}$.).

When the stone tumble was removed, it exposed the destroyed section of wall 1 (Fig. 5) and produced a LH IIB Ephyraean goblet fragment (P 704, Lot 35) as well as other decorated sherds (P 705-P 707, Lot 35; P 711, P 712, Lot 39). This disturbance seems to be a distinct level (II). It postdates level III (Structural Phase 2), which appears to include a structure of Late Helladic I date (Fig. 4). Level III consists of the stone-clay surface mentioned above which extended westward into grid EEE/18-19/18 and southward into $\mathrm{EEE} / 19-19 / 19$ between the stone-clay surface and the base to the west (Fig. 4). Lying flat and upside down against the stone base in EEE/17-19/19 was a monochrome, red-painted goblet base of probable LH I date (P 719). These finds in conjunction with the discovery of a chert-nodule fragment (ST 549) and two red monochrome bowl sherds (Lot 33-LH I) on the clay-stone surface indicate a probable LH I level. ${ }^{24}$ Whether or not this level was bounded by walls is not clear, although the uppermost corner of wall 1 was preserved above this floor level and retained mud-brick fragments and a line of stone along its north face that may represent a second phase of use (see below, p. 395).

Aside from these ill-preserved traces of a later occupation the remainder of the surface exposed beneath the plowing was destruction debris from the original building (in Level IV, Fig. 3). This material was cleaned and examined. Although it was possible in several instances to isolate fragments of mud brick, none was complete enough to give more than one dimension. Of the roof debris, however, fragments of burnt clay preserving the impressions of ceiling reeding were recovered. ${ }^{25}$ Mixed in with and, more frequently, under this debris was an abundance of charred material, mostly wooden timbers but also floral remains. Clearly, we thought, fire had contributed to the destruction of the building. This became more apparent as work proceeded to clear away the remains. In grid EEE/17-19/18 a large, burnt stump was uncovered, and in grid EEE/20-19/19, just south of and below the

${ }^{24}$ Lot 33 is characterized by much brittle green ware, some of which is matt-painted and has lobed handles, and by dark-coated lustrous ware, and matt-painted polychrome wares (see discussion below, p. 389).

${ }^{25}$ See, for example, ceiling fragments from House G at Eutresis: H. Goldman, Excavations at Eutresis in Boeotia, Cambridge, Mass. 1931, pp. 62-63, fig. 71. 


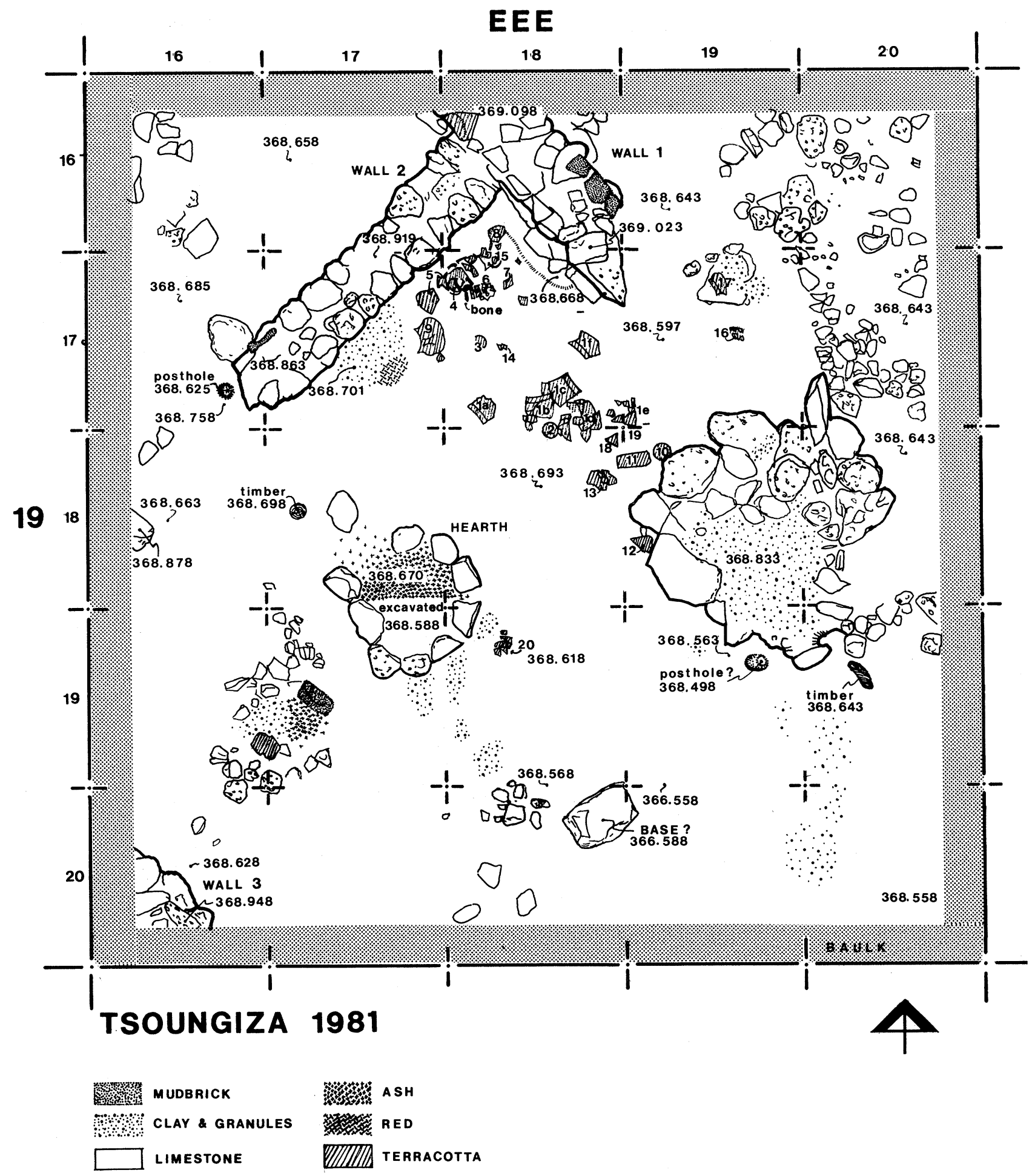

FIG. 5. Tsoungiza, actual-state plan 
stone-clay surface, a larger, better preserved log fragment was excavated. These were wrapped in tin foil and will be submitted for dendrochronological examination. Samples were also taken for Carbon 14 analysis. Other traces of timber were exposed in grid EEE/18-19/17 within the angle of walls 1 and 2 (Fig. 4); these were about $0.60 \mathrm{~m}$. long and had fallen parallel to the walls. Behind wall 2, in what apparently formed a back room to the structure, virtually a string of carbonized bulbs turned up. These appeared in grid EEE/17-19/16 and were found in four clumps spaced vertically apart within and above the mud-brick debris from wall 2. Each contained a nest of cloves, the total number exceeding 300. They have not been identified, but they bear resemblance to wild garlic, a member of

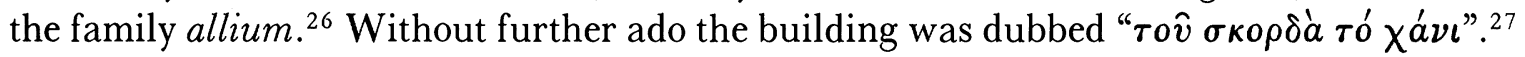

Upon removal of the destruction debris the floor of the building was encountered. The broken fragments of many pots were lying on it, primarily within the angle of walls 1 and 2 (Fig. 5, Pl. 89:b). Also exposed was the continuation of wall 2 to the southwest; it stops in grid EEE/16-19/17, and next to it in the floor we cleaned out a post hole about $0.09 \mathrm{~m}$. in diameter and about $0.12 \mathrm{~m}$. deep (Pl. 90). No burnt debris filled this hole. Beyond, in $\mathrm{EEE} / 16-19 / 18$, a line of stones continues the line of the wall to the baulk; projecting from the baulk are several courses of rubble that presumably form the continuation of the wall. Thus we recognized a door leading from the main room westwards into the back room where the cloves were found. The small area excavated within this back room was barren of other finds.

Continuing exposure of the floor with the vessels on it showed that the stones facing the clay surface of level III floated in the fill and bore no relation to the floor. Removal of the roof debris and mud-brick remains scattered across grids EEE/17, 18-19/18, 19 revealed a circular stone hearth (Fig. 5, Pl. 90) filled with ash. Excavation in the southwestern corner grid EEE/16-19/20 disclosed the interior face of wall 3, parallel with wall 1. The hearth lies midway between the walls, and the width of the room is $4.10 \mathrm{~m}$. Southeast of the hearth on the axis of the room in grid EEE/18-19/20 a rectangular stone base appeared; it is on the axis of the room, equidistant from the side walls 1 and 3 , and is $1.10 \mathrm{~m}$. from the hearth and $2.75 \mathrm{~m}$. from the cross wall 2. These alignments suggest that the stone was a base for a post. Moreover, they show that the door leading into the back room is off center, perhaps to allow the wall end of wall 2 to align with the column and thus to be part of the central roof support.

Scattered around the floor of the room were several burnt areas that do not seem to have resulted from the conflagration of the building. In two cases these were encircled by small stones and contained whitish clay. One other, set against wall 2 (Fig. 5, Pl. 90), was made of a thick packing of clay with traces of a red soil. The original purpose of these features is not clear. One in grid EEE/17-19/19, however, had over it a line of ashes that connected with the overflow of ash from the hearth. Perhaps these features were used for subsidiary fires outside the central hearth. In grid EEE/19-19/19 a post hole was discovered, ca. $0.065 \mathrm{~m}$. deep.

${ }^{26}$ These will be examined and identified by Dr. Julie Hansen. I wish to thank her for advising me that they may be of the family allium.

27 "The Inn of the Garlic". 
The floor of the room was made of tamped earth, especially using stone granules of thumb and forefinger size mixed with white marl. This floor was difficult to isolate in the area where it was covered by the fallen pottery, but its termination along the line of the robbed-out portion of wall 1 was detectable. Excavation in adjacent grids will no doubt clarify the existence of some of these features as well as define the extent of the remains. What has been uncovered, however, allows the prediction that another cross wall with a front door in it will be discovered at the southeast. Perhaps it will open onto a porch as is common with other such buildings on the mainland. To the northwest we may expect to find the remnants of the back room. As a whole the building is probably a freestanding, rectangular structure, perhaps with an apsidal or rectangular end. The width can be calculated to about $5.10 \mathrm{~m}$. and the length about $8.5 \mathrm{~m}$. or greater. ${ }^{28}$

\section{G. Pottery and Date}

The pottery on the floor was carefully plotted and taken up for mending. The result was the restoration of eight complete vessels and fragments of numerous others (Pl. 91:a). As is clear from the photograph, this deposit represents a homogeneous unit: two kantharos cups (P 722 and P 708), a goblet (P 716), two jugs with cut-away spout (P 723, P 724), a ladle (P 685), and two conical jars (P 740, $\mathrm{P} 741$; only one is shown in the photograph). Entirely domestic in character, the deposit is lacking imported and painted wares; this is also true of the sherd material recovered from the floor (Lot 38; see discussion below).

A lack of time did not permit detailed study of the deposit material. Only preliminary description and brief comments will be offered here.

\section{P 685 Ladle}

Diam. of rim $0.11 \mathrm{~m}$.

Surface: very pale brown to yellow (10YR 7/5)

P 708 Kantharos cup

H. 0.147 m., H. to rim 0.113 m., Diam. of rim $0.159 \mathrm{~m}$.

Surface: pink to very pale brown (7.5YR 8/5 to $10 Y R 7.5 / 4$ )

P 716 Goblet

H. 0.159 m., Diam. of rim 0.177 m.

Surface: very pale brown (10YR 7.5/3)

P 722 Kantharos cup

H. 0.107 m., H. to rim 0.081 m., Diam. of rim $0.106 \mathrm{~m}$.

Surface: pink to reddish yellow $(7.5 \mathrm{YR} 8 / 5)$

\section{P 723 Jug with cut-away spout} H. $0.193 \mathrm{~m}$.

Surface: pale yellow (5Y 7.5/3)

P 724 Jug with cut-away spout

H. $0.159 \mathrm{~m}$.

Surface: light gray to white (5Y 7.5/2)

P 740 Conical jar

H. 0.269 m., Diam. of base 0.048 m., Diam. of rim $0.198 \mathrm{~m}$.

Surface: reddish yellow (5YR 7/7)

P 741 Conical jar

H. 0.284 m., Diam. of base 0.052 m., Diam. of rim $0.205 \mathrm{~m}$.

Surface: light red (5YR 5.5/6)

The vessels are of three distinct fabrics which correspond well to most of the sherd material. ${ }^{29}$ The ladle, cups, and goblet are of the burnished yellow fabric usually called

${ }^{28}$ See, for example, House D at Eutresis: Goldman, op. cit. (footnote 25 above), p. 56, fig. 63; C. W. Blegen, Korakou, New York 1921, House F, pp. 76-77.

${ }^{29}$ In defining our fabrics we have followed A. O. Shepard, Ceramics for the Archaeologist, Washington, D.G. 1956, pp. 102-121. 
Yellow Minyan. The surface colors vary from very pale browns to yellows on the Munsell 10YR chart. The fracture shows incomplete oxidation with a pale exterior and a very light gray interior. Inclusions measured on the Wentworth scale are from very fine to coarse $(1 / 8-1 / 2 \mathrm{~mm}$.).

The second fabric is greenish and often burnished or matt-painted. To it belong the jugs. The surface color is pale yellow on the Munsell $5 \mathrm{Y}$ chart. The fracture is usually clear, indicating full oxidation, and the sherds have a brittle quality. The inclusions are very fine to fine $(1 / 8-1 / 4 \mathrm{~mm}$.).

The third fabric is yellow, burnished, and coarse, a variation of the more commonly encountered yellow plain fabric of these levels. The two storage jars belong here. Surface color varies from reddish yellow to light red on the Munsell 5YR chart. The fracture is clear, showing full oxidation, and the inclusions are coarse, from $1 / 2$ to over $1 \mathrm{~mm}$. in size.

The shapes and fabrics of these vessels are closely related to types commonly found dating to the end of the Middle Helladic period, particularly in the Argolid. What is especially noteworthy of our deposit, however, is that it comes from a settlement context, whereas most of the contemporary published deposits are from tombs. ${ }^{30}$

The most distinctive and best studied type among the vessels is the goblet P 716. Similar ones were found in abundance in the tombs of Grave Circle B and were discussed and categorized by Mylonas. ${ }^{31}$ Recently, S. Dietz has placed special emphasis on the two distinctive types of goblet as a result of his study of the Asine tumulus burials. ${ }^{32}$ The early type, Group 1, is characterized by a conical body and incised rings around the base of the outer wall, while the later Group 2 type shows a fuller, rounder body, a lower foot, and no rings around the lower outer wall. P 716 is clearly an example of the latter group (Pl. 92:a). ${ }^{33}$ It differs from the Asine examples only in being fuller in form with its handle more integrated to the contour of the body. The vessel compares equally favorably with those of the late graves $\Gamma, \mathrm{O}, \mathrm{M}$, and $\Pi$ of Circle $\mathrm{B} .{ }^{34}$

The kantharoi (P 708 and P 722, Pl. 92:b, c) also stand in good comparison to examples from the same deposits at Mykenai and Asine. ${ }^{35}$ These three vessels (goblet and kantharoi) are closely related in shape: from a broad base rises a full, squat body to a distinctive, high angular shoulder (P1. 92:a, b). P 708 and P 716 are the most similar. Notice the

${ }^{30}$ Dr. Carol Zerner kindly informs me that similar domestic units have been found at Lerna. I thank Professor Jack L. Davis for discussing the floor deposit with me.

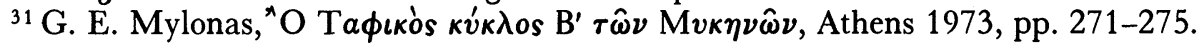

${ }^{32}$ S. Dietz, Asine, II, ii, The Middle Helladic Cemetery, The Middle Helladic and Early Mycenaean Deposits, Stockholm 1980, pp. 80-81.

${ }^{33}$ Ibid., nos. 21, 22, 30, 32.

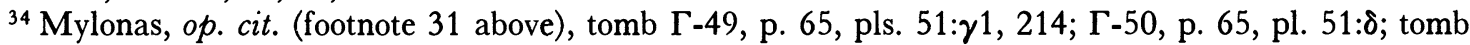
O-216, p. 198, pls. 176, 217; tomb M-137, pp. 150-151, pls. 130:a, 216; M-138, p. 151, pl. 130: $\gamma ;$ tomb П-218-П-220, pp. 208-210, pl. 191. For a discussion of the order of the graves, see O. T. P. K. Dickinson, The Origins of Mycenaean Civilisation, SIMA 49, 1977, pp. 40-46, contra Mylonas, op. cit., p. 354.

${ }^{35}$ See Dietz, op. cit. (footnote 32 above), nos. 34, 38, p. 43, figs. 43, 44, 50, 57; Mylonas, op. cit. (footnote 31 above), tomb $\Gamma-21-23$ (pls. 43, 234); a matt-painted predecessor of the cup is seen in tomb A7 (pls. 15, 234). 
unbroken contour line from the lower body to the tip of the handles. Perhaps they are all products of a local workshop.

The ladle is of the same fabric and can be compared to Middle Helladic examples of Class A III from Korakou. ${ }^{36}$ Examples of this domestic utensil are notably lacking from contemporary graves. The two jugs (P 723, P 724) are a frequently occurring Middle Helladic shape, usually bearing matt-painted decoration. ${ }^{37}$ The two storage jars do not find parallels in published reports. Similar forms, but lacking the distinctive incurved shoulder and high collar rim of ours, are found at Mykenai and Asine. ${ }^{38}$

These comparisons strongly suggest that the deposit dates to the later period of Grave Circle B, or to Dietz's MH IIIB phase. ${ }^{39}$ The coining of this new subdivision has been questioned, since, as Dietz himself points out, it is contemporary with LH I. ${ }^{40}$ The absence of any trace of LH I from this deposit is consequently of considerable interest. The apparent relation to later Grave Gircle B is reinforced by the character of the sherds recovered from the floor deposit (Lot 38, 953 sherds, 8,480 g. excluding whole vessels), ${ }^{41}$ which consists almost entirely of undecorated material. A few examples of dark-coated lustrous ware and monochrome red-painted ware were found, as well as one matt-painted, bridge-spouted jar spout (P 721). Rims of deep, gobletlike bowls also appear. ${ }^{42}$ Nothing is demonstrably LH I at this stage of study. This conclusion is buttressed by examination of the overlying material (Lots 33, 37), which contains more dark-coated lustrous ware, matt-painted polychrome ware and strap handles that terminate in two lobes which attach to the rim. The added lobes are curiously like the characteristic applied pellets or rivets observed on vessels from Grave Circle B and in the LH I deposit at Korakou. ${ }^{43}$ Nothing else, however, need be of LH I date. Further study will no doubt establish more clearly the stylistic and typological distance between the floor deposit and the destruction layer. At present we may be justified in tentatively asserting that the date of these levels is immediately prior to Late Helladic I. If this is borne out, then the value of the deposit and the need to excavate further will be clear, as one of the more forcefully stated requirements of ceramic studies of this period is for a series of well-established domestic levels from the northeastern Peloponnesos. ${ }^{44}$

${ }^{36}$ Blegen, op. cit. (footnote 28 above), fig. 26 and p. 19.

${ }^{37}$ In general, see R. J. Buck, "Middle Helladic Mattpainted Pottery," Hesperia 33, 1964, shapes B9, B10, pp. 246-247, 286-287, pl. 40; and matt-painted examples from Circle B: Mylonas, op. cit. (footnote 31 above), tomb A-5 (pls. 14: $\gamma, \delta$ and 220), tomb $\Gamma-34$ (pls. 47:a, 227).

${ }^{38}$ Cf. Asine: A. Persson, Asine, Stockholm 1938, p. 280, fig. 193:11 (a MH coarse jar of similar size and with a narrow disk foot); Mykenai: Mylonas, op. cit., tomb O-205, pl. 172: $\beta$, p. 195.

${ }^{39}$ Dietz, op. cit. (footnote 32 above), pp. 80-81, 87-88, 141-144.

${ }^{40} \mathrm{~J}$. Davis, review of Dietz, Asine II, ii, $A J A$ 86, 1982, pp. 136-138.

41 This material constitutes all the pottery recovered in the level over the floor and can be safely considered to be destruction debris. Clearly much of it consists of earlier material that had been embedded in ceiling and walls which collapsed; some, however, should also be discarded material contemporary with the latest occupation of the structure. None of it appears later than any of the complete vessels; see also discussion below, pp. 394-395. The terms used here are those of Davis' article, below, footnote 42.

${ }^{42}$ See J. Davis, “LH I Pottery from Korakou," Hesperia 48, 1979, pp. 241, note 23, 254.

${ }^{43}$ Ibid., p. 252 and note 59.

${ }^{44}$ See O. T. P. K. Dickinson, “The Definition of Late Helladic I," BSA 69, 1974, pp. 118-120; Davis, op. cit. (footnote 42 above), pp. 253-259; Dietz, op. cit. (footnote 32 above), pp. 141-144. 


\section{Interpretation}

Although only partial remains were uncovered in this small trench and future work will reveal much more of the structure in it, it is possible to suggest an interpretation of the phases of occupation and of the nature of the destruction of the first building. Because the excavation was designed with certain research interests in mind, the evidence for interpretation is especially clear. The work was begun with the understanding that recovery of artifacts and organic material and close recording of context would provide evidence for reconstructing the events that placed the material there. Likewise, it was assumed that the interrelations of these materials would be the only evidence for the systems of human behavior that obtained prior to the deposition of the objects. This required the further assumption that those interrelations were somehow linked to the spatial location of each of the objects. ${ }^{45}$ Thus when, during the course of excavation, we encountered fallen mud-brick debris and burnt timbers, we hypothesized that the building had been destroyed by fire. Upon the discovery of the floor deposit, this hypothesis seemed susceptible to testing. Numbers were assigned to the concentrations of sherds on the floor (Fig. 5). After the sherds were drawn and photographed, they were lifted, cleaned, and then spread out by their numbered groups and labeled. As the restoration proceeded one of our team (De Mita) plotted the position of the sherds making up the restored vessels on a plan of the floor. The position of the sherds in the vessel (base, lower body, upper body, neck, shoulder, handle, and rim or spout) was also noted. The series of diagrams in Figures 6 and 7 result from this procedure. Analysis of the diagrams enables us to examine the following questions:

1) Was the deposit disturbed after its original deposition? If so, how?

2) What can the deposit tell us of the nature of the destruction?

3) Does the position of the deposit provide indications of the pottery's use or position before the destruction?

Answers to the first set of questions are based on the assumption that a disturbed deposit would show irregular spatial mixing of the sherds of each vessel such that no distinct patterns of distribution per vessel would be detectable. Also, disturbance would probably disperse some of the sherds outside the confines of the room of the deposit, and they would not all be recovered. Explanations of such disturbance could be sought in deliberate strewing of the remains by human agency, such as through violent destruction of the building, or through later occupation, or by such post-occupation activities as plowing. ${ }^{46}$

Plotting the scatter of sherds per vessel produces the diagram Figure 6. Clearly the vessels form mostly discrete units; their sherds are limited within a range of a square meter

${ }^{45}$ See above, footnote 16; The Early Mesoamerican Village, K. Flannery, ed., New York 1976, chap. 2.

${ }^{46}$ The concept of studying spatial patterning by refitting, which is applied in the following discussion, has been demonstrated in an exemplary study of the lithic assemblage of the Late Palaeolithic site of Meer in Belgium: D. Cahen, L. H. Keeley, F. L. Van Noten, "Stone Tools, Toolkits, and Human Behavior in Prehistory," Current Anthropology 20, 1979, pp. 661-683; idem, "A Paleolithic Campsite in Belgium," Scientific American 242 (4), 1980, pp. 48-55; reviewed by T. Douglas Price, Quarterly Review of Archaeology, pp. 1-5. The question of possible disturbance of the deposit is critical to all other explanation of the artifact deposition since it concerns the distinction between primary and secondary refuse; see $\mathbf{M}$. B. Schiffer, Behavioral Archaeology, New York 1976, pp. 30-31; P. Villa, "Conjoinable Pieces and Site Formation Processes," American Antiquity 47, 1982, pp. 276-290. 


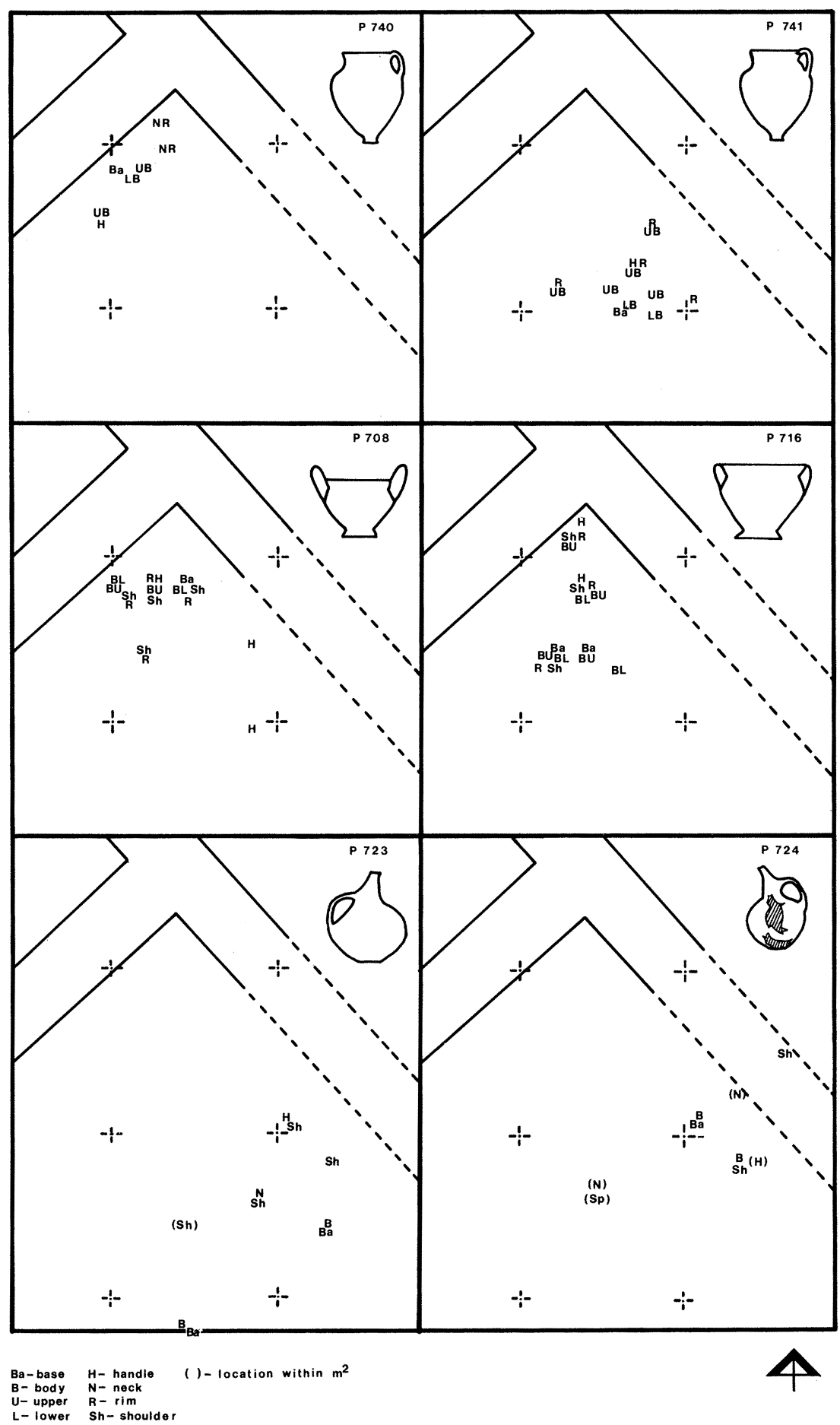

FIG. 6. Floor deposit, distribution of sherds per vessel 
except for those distributed linearly, in which cases the dispersal is about two meters long. Two vessels, $\mathrm{P} 722$ (the small kantharos cup) and P 685 (the ladle), were recovered from single locations showing virtually no dispersal. Two others, the jugs P 723 and P 724 (Fig. 6), were widely distributed. One possible explanation for the different dispersal pattern exhibited by the jugs would be that these vessels are more brittle (see description above, $p$. 388 ) and that their thin walls in combination with their more globular shape would make them more subject to exploding, so to speak, when thrown down. Simple visual comparison of the size of the sherds among the vessels bears this out (cf. Pl. 91:a), as does close comparison of the jugs' pattern of distribution to those of the heavy, coarse-ware conical jars, P 740 and $\mathrm{P} 741$, which are much more limited. But the absence of some sherds from jug P 724 (Pl. 91:a) is disturbing, since it implies that the missing sherds were not retrievable within the excavated area of the room. Furthermore, the discovery of shoulder fragments outside the robbed line of wall 1 (Figs. 6,7) may indicate that this vessel, and perhaps the area of its original scatter of sherds, was disturbed. (Of course it is possible that the missing sherds may be found under the later-built area of the stone-clay surface in EEE/19-19/18 and that the missing area of wall 1 contained a doorway, but in either case one should then wonder why the other jug, P 723, with its similar position and pattern of distribution, was recovered complete and entirely within the projected boundaries of the room.) There were no signs that the modern plowing which had disturbed the upper levels of the trench had penetrated deeply enough to redistribute the sherds. If it had, the plowing should have been detectable in the presence of rillets from the plow-tip in the floor. Also, the concentration of the LH I and II sherds only in the area of the robbed-out wall is independent evidence of a late disturbance (Level II, above, p. 384). Thus we are justified in concluding that the deposit was partially disturbed in the area of the jug P 724, probably during LH I or II.

To answer the second question, concerning the nature of the destruction, we are provided with two kinds of evidence. First, the lack of disturbance and mixing of the remains may argue against human agency, if we consider that humans sacking a building might throw, kick, and knock objects about. Second, the tight patterns of the sherds and the debris of burnt beams and mud brick or daub above them would indicate that the deposit was sealed about the time of the destruction. Third, the differential burning of the sherds shows that the vessels were not burned but that individual sherds were brought into contact with fire, probably from beams and other inflammable debris (see Pl. 91:a). Indubitably the building was burned, but whether or not that constituted the sole cause of destruction should be questioned. An alternative explanation would be that the building was partially thrown down by an earthquake and then burned. In this case the vessels would be thrown from their resting places to the floor and then burned when the timbers and other inflammable debris from the house fell upon them. There is, however, no demonstrable evidence of earthquake destruction such as twisted, buckled, split, or fallen walls. ${ }^{47}$

Experimental work with burning similar structures has been carried out. Usually the results have shown that fire damages but does not burn to the ground buildings of wattle and

47 There are numerous examples of destruction in prehistoric times attributed to earthquake, e.g. Troy VI, Knossos, houses around Mykenai, but no studies I have consulted offer comparative examples of the damage from known earthquakes to damage thought to be recognized in the archaeological record. 


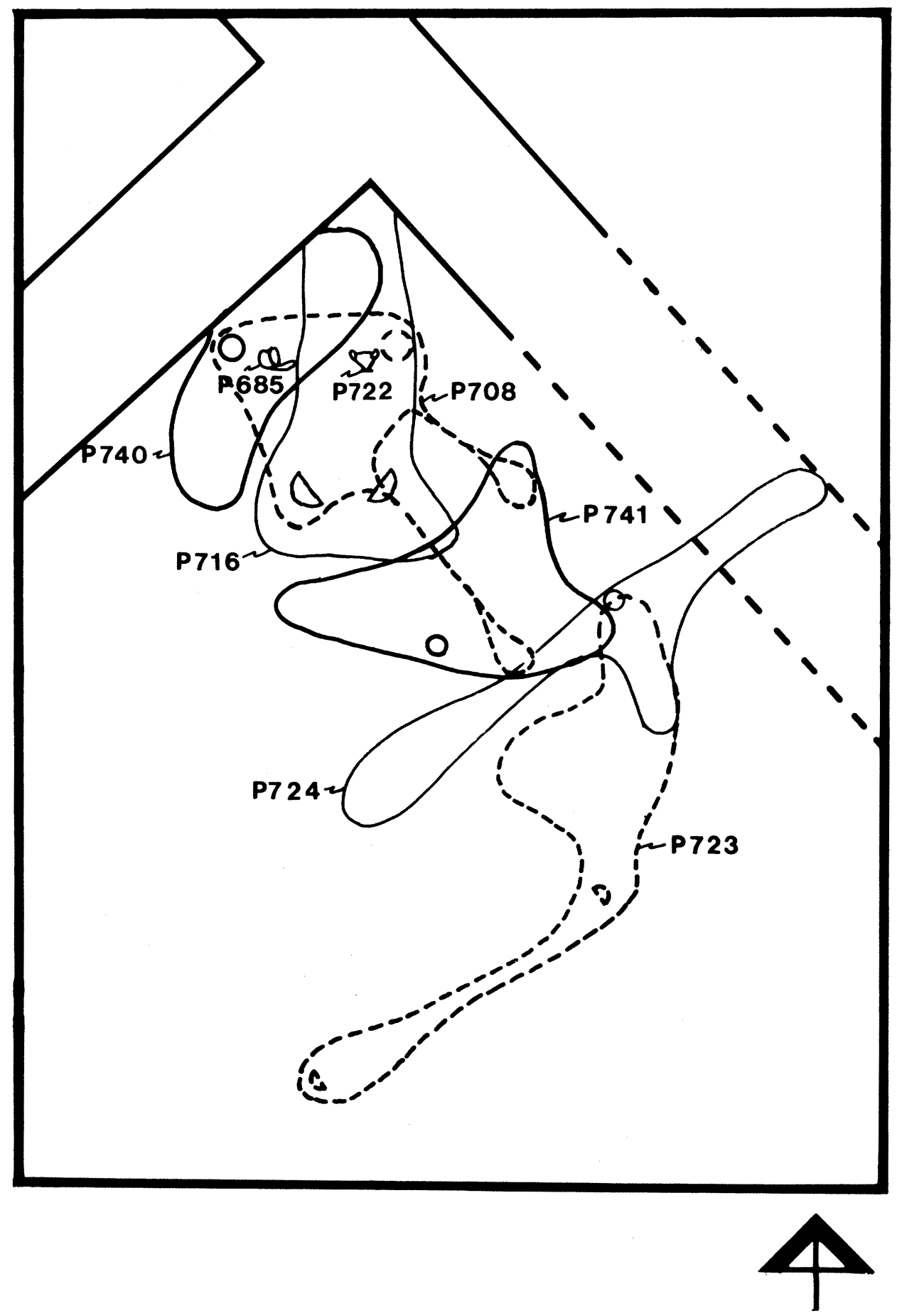

FIG. 7. Floor deposit, patterns of sherds per vessel 
daub or mud brick. ${ }^{48}$ The damage is mostly done to ceiling and roof which collapse into the interior. Such an event would account for the differentially burned sherds of the vessels in our floor deposit; they would have fallen and scattered in pieces across the floor and subsequently been burnt by flaming debris falling helter-skelter upon them. Likewise, the many burnt allium cloves could be explained by such a reconstruction of events. Their discovery in discrete clusters separated vertically through the mud-brick debris along the face of the cross wall may suggest that they fell among debris from the burning wall and roof.

The third question, concerning the relation of the fallen vessels to their original position, is not easily answered. Once again the distribution of the sherds provides two forms of evidence. The total pattern by vessel shows that they fell in a line along the interior of wall 1 and therefore were probably stored along this wall. Did the vessels fall from a shelf or from a niche in the wall? The dispersal patterns seem great enough to hypothesize that the vessels fell from some height. To determine how high would require experimentation with similar pots. Related experiments could be conducted to determine the trajectory of the vessels as they fell to the floor. There are, however, many uncontrollable variables at work in such an experiment, and it does not appear at this point to be a fruitful line of investigaton. ${ }^{49}$

The original order of the pots might be reconstructed from their distribution patterns (Fig. 7). The conical storage jar P 740 and the ladle P 685 were found together with body sherds of the jar directly under the bowl and handle of the ladle, and the bowl was nestled against the interior of the base of the jar (Pl. 91:b). Also in this jar were found a bone and a stone tool. These items were almost certainly stored in the jar which was located at the angle of walls 1 and 2. Next to them would have been the large kantharos P 708 and the small one $P$ 722. Then further along the line of wall 1 was placed the goblet P 716. Next to it would have been the second conical jar P 741, and last the two jugs, P 724 and P 723, in that order.

\section{E. Conclusions}

The evidence allows us to conclude with a considerable degree of certainty that the building was destroyed by fire toward the very end of the Middle Helladic period. As a preliminary hypothesis the lack of material objects other than pottery may indicate that the occupants had time to remove valued items such as metal and stone artifacts and, perhaps, valued foodstuffs. ${ }^{50}$ Future excavation will take care to isolate other activity and storage areas of the building. The pottery recovered from the floor is notable for its domestic character. It represents three major functional categories: storing, pouring, and drinking; is grouped predominantly in pairs; and lacks any trace of decoration or influence of imported vessels.

After the destruction of the building, it seems work began immediately to build again upon the foundations. Three observations suggest this interpretation. First, the stone and

${ }^{48}$ See J. Coles, Experimental Archaeology, New York 1979, pp. 150-158, especially the comments on mud brick; F. Winter and H. Bankhoff, "A House-burning in Serbia," Archaeology 32, 1979, pp. 8-14.

${ }^{49}$ Some of these variables would include the height and velocity of fall, the angle of incidence, the weight of the base relative to the body, the position of the vessel when commencing to fall, and the uniformity or non-uniformity of the floor surface.

${ }^{50}$ Coles (op. cit. [footnote 48 above], p. 154) discusses the time allowed to remove valuable objects from a burning, thatched dwelling and suggests that often such burning may have been deliberate, thus accounting for the frequent paucity of artifacts discovered by the archaeologist. 
clay surface was erected above the floor deposit and at a level corresponding with the large, square stone base (Fig. 4). Second, the line of stones and mud-brick fragments in situ on top of but offset from the faces of wall 1 indicate a secondary wall. The base elevation of this wall socle $(+368.99 \mathrm{~m}$.) corresponds closely to that of the stone base $(+368.928 \mathrm{~m}$. $)$ and the platform $(+368.873-368.943 \mathrm{~m}$.). Third, there is a tumble of mud-brick debris in the area of the cross wall. ${ }^{51}$ When one considers the burnt allium cloves within the debris this might be interpreted as a possible dismantling of the standing remains of the burnt building: if they had not been buried soon after their carbonization, they would quickly have disintegrated. Instead they were found preserved in situ among and sealed by a uniform layer of mud-brick debris. This material was well defined along the northwest face of wall 2 and was stratified above a layer of ash and burnt remains which seems to constitute the primary destruction level. It would appear that the standing ruins had been leveled for construction of a new building. The upper levels of this debris contained dark-coated lustrous ware, red monochrome goblet rims and bases, and other pottery possibly of LH I date (see discussion above, p. 389).

These suggested events will provide a good working set of hypotheses for continuing excavation of the building. Future work will also concentrate on clarifying the presence of the LH II disturbance outside wall 1.

\section{Future Prospects}

Although the focus of this season's activity by chance was on these late Middle Helladic remains, this stratum of the site is by no means the dominant one. Early Helladic and Neolithic levels are abundant: Harland's work in 1926/27 uncovered many houses of EH date on the crest of the hill. Deep plowing widely different areas of the hillsides has disturbed considerable remains of both periods. There is, however, no way of ascertaining the extent and nature of occupation on the site as long as it is excavated only as salvage work becomes necessary. The final result of such an unsystematic uncovering of Tsoungiza would be an incoherent and unfocused picture of the site and the irrevocable loss of its value as a major prehistoric site in the Argolid-Corinthia.

Although J. P. Harland's manuscript for the 1926/27 excavations provides considerable information about the Early through Late Helladic levels of Tsoungiza, it is inadequate as a record by today's standards. Much information has come to light since those early years of research, and questions raised in reading the manuscript cannot be easily answered by a re-examination of the finds, many of which are no longer available. The results of this season's activities and the sum of work since 1974 leave little doubt that there is considerable material remaining to be excavated on the hill.

Any attempt to investigate these remains must be accompanied by a plan of research that on the one hand recognizes the salvage nature of much of the work to be done and on the other hand places the project in the perspective of the prehistory of the surrounding region.

51 The collapse of mud-brick walls has been the subject of a number of studies; see Coles, op. cit., p. 155; R. M. McIntosh, "Archaeology and Mud Wall Decay in West African Villages," World Archaeology 6, 1974, pp. 154-171. 
In this regard the best strategy would be to define the limits and conditions of the site before further excavation and to explore the relationship of the site to the environment and history of human activity in the valley.

With these goals in mind work in the future would test the stratigraphy and surface geology of the site by means of cores taken at intervals of 10 to 20 meters across the hill of Tsoungiza. The method would employ a hand-operated auger which would be virtually non-destructive in its use. Soil samples would be taken, and absolute levels recorded. In this manner we should be able to define economically and efficiently the boundaries of occupation at the site during its range of occupations. This would much simplify planning for future excavation and help to verify areas of suspected deep stratigraphy.

Discussions would also take place on the feasibility of a survey of the valley to explore patterns of human use and to define its ecological zones. This work would, of course, be directed at clarifying the context of the valley in the history of the surrounding region. Questions to direct this work can already be phrased. For example, the deep alluvial deposits of the valley floor (above, p. 378) that postdate ancient occupation effectively eliminate a large area of the valley from study. How large an area? Where are the boundaries of the alluvium? To what extent do the excavations in the sanctuary help in the reconstruction of the prehistoric valley floor?

Other questions arise when one considers the history of occupation on Tsoungiza. The survey will need to search for settlements contemporary with those represented at Tsoungiza and also for those not represented. The excavation on the hill should be organized in such a manner as to provide a standard of comparison for the survey evidence. Evidence from the survey and site will need to be placed in reference to our understanding of the respective periods of occupation in the surrounding regions. This requires devising a plan of research for each time period represented or likely to be significant at the site or in the valley. Moreover, a general consideration of the geographical position of the Nemea Valley is necessary in order to develop hypotheses about the network of relations in which Tsoungiza and the valley might have been involved.

At present it appears that the most abundant remains at the site will be Early Neolithic and late Middle Helladic. Depending upon the amount of deep stratigraphy accessible, some earlier Middle Helladic and Early Helladic remains may also be recovered. Experience has shown that the Late Helladic remains, although widespread and considerable, are mostly superficial. Without elaborating, it is worth pointing out that the existence of considerable deposits of $\mathrm{EN}$ and $\mathrm{MH}$ material is particularly encouraging. Settlements of neither period are well known from our wider region. For the Early Neolithic the opportunity to investigate the nature of early agricultural and subsistence practices in the foothill regions of the Peloponnesos and to compare the settlement remains to those recovered at Lerna and, especially, at Franchthi will allow the formulation of many important questions about early human settlement in the northeastern Peloponnesos. ${ }^{52}$ For the Middle Helladic, questions relating to the nature of the economy of this period can be phrased, in particular as they

${ }^{52}$ E.g. T. W. Jacobsen, "The Beginning of Settled Village Life in Greece," Hesperia 50, 1981, pp. 303-319. 
relate to the beginnings of centralization as witnessed by the Shaft Graves of near-by Mykenai. The building excavated this year and the floor deposit in it already go some distance toward providing additional valuable evidence for this crucial period in Greek prehistory. Both survey of the valley and excavation of Tsoungiza will form a proper complement to the present work in the Sanctuary of Zeus. In this way the activities begun under the leadership of B. H. Hill and C. W. Blegen over fifty years ago will be brought to a successful and satisfactory conclusion.

Bryn Mawr College

James C. Wright

Department of Classical and Near Eastern Archaeology

Bryn Mawr, PA 19010 


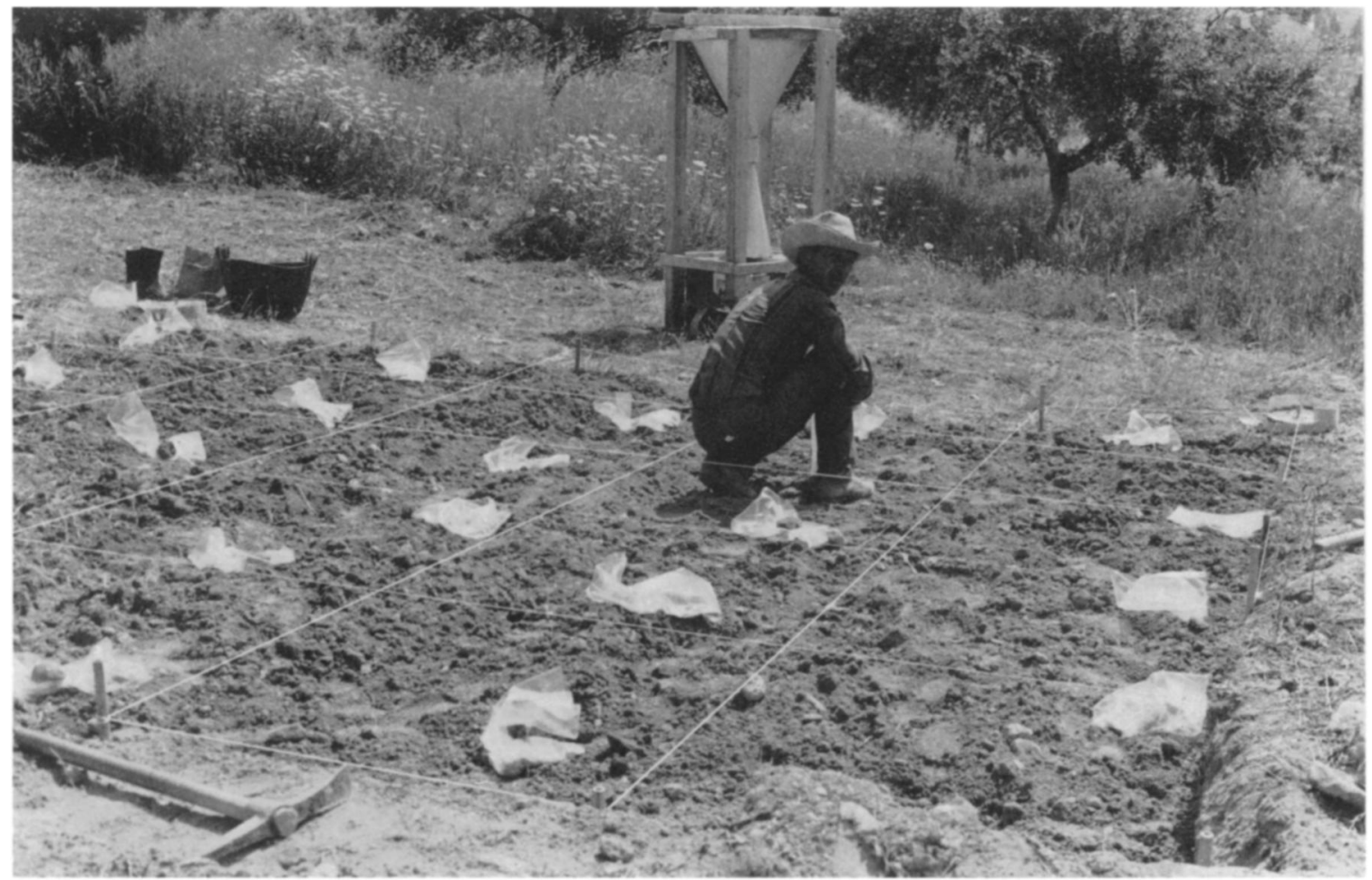

a. Trench EEE/16,20-19/16,20 with sample splitter in background, from west

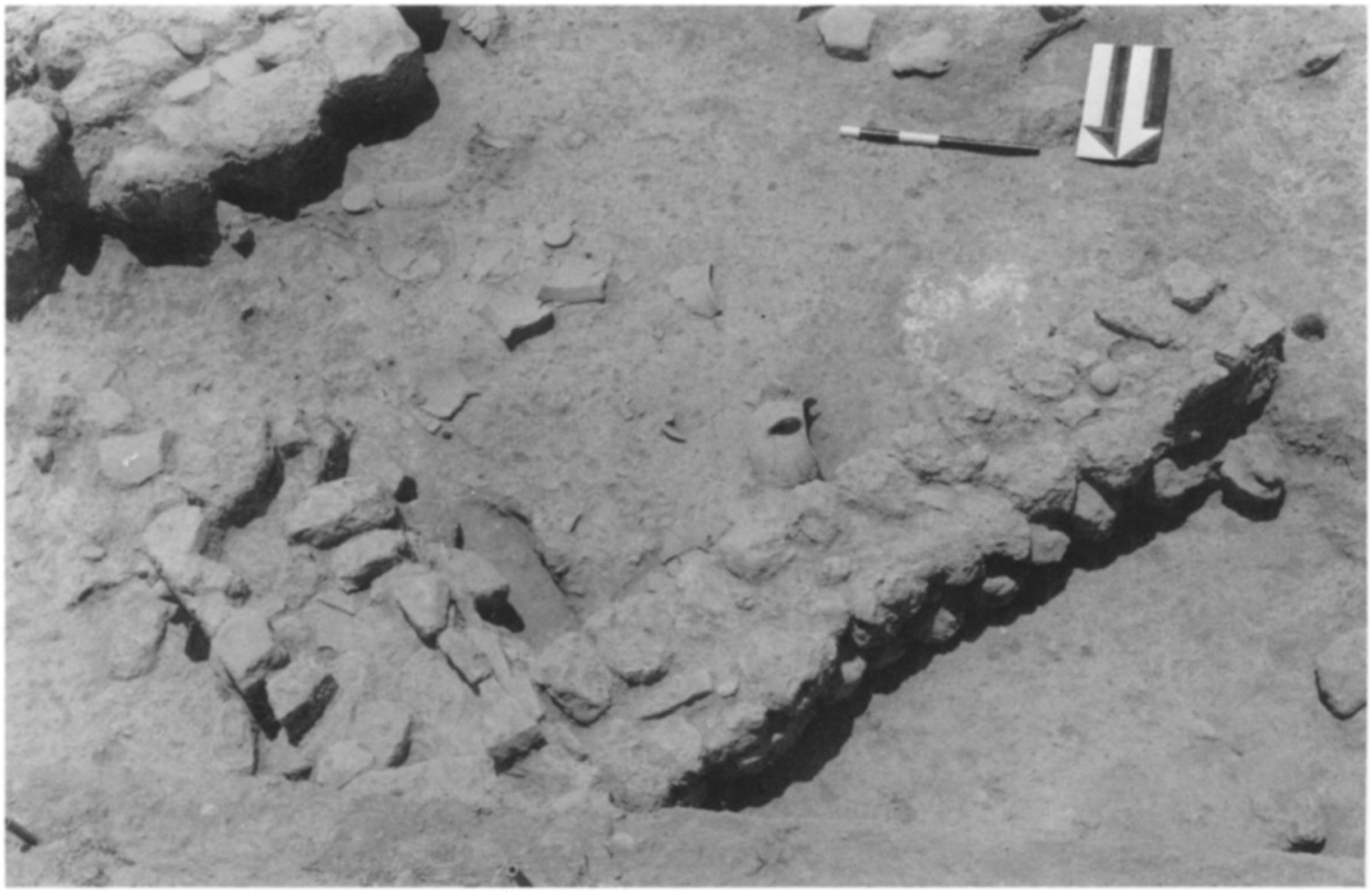

b. Trench EEE/16,20-19/16,20, pottery on floor, from north 


\section{PLATE 90}

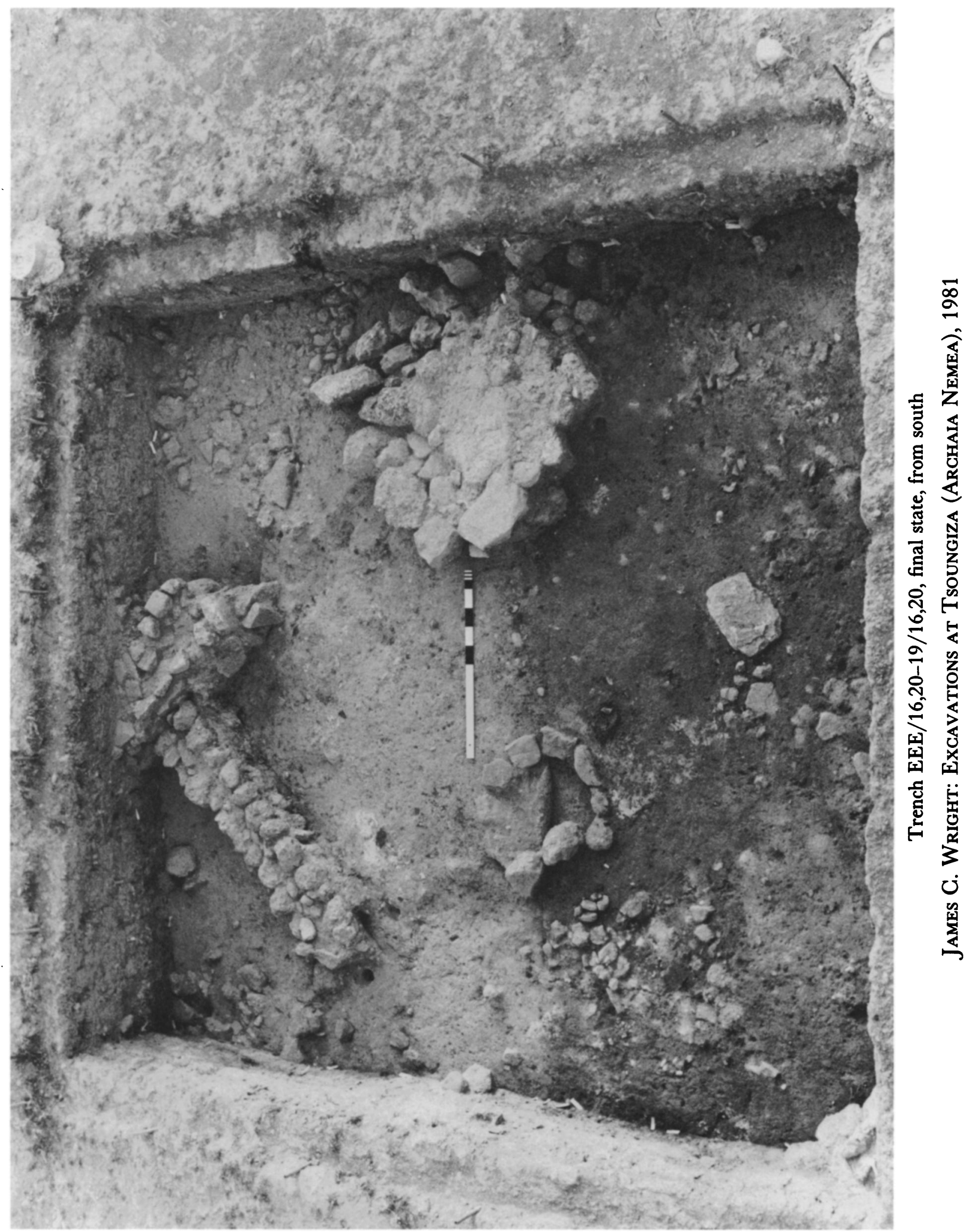


PLATE 91

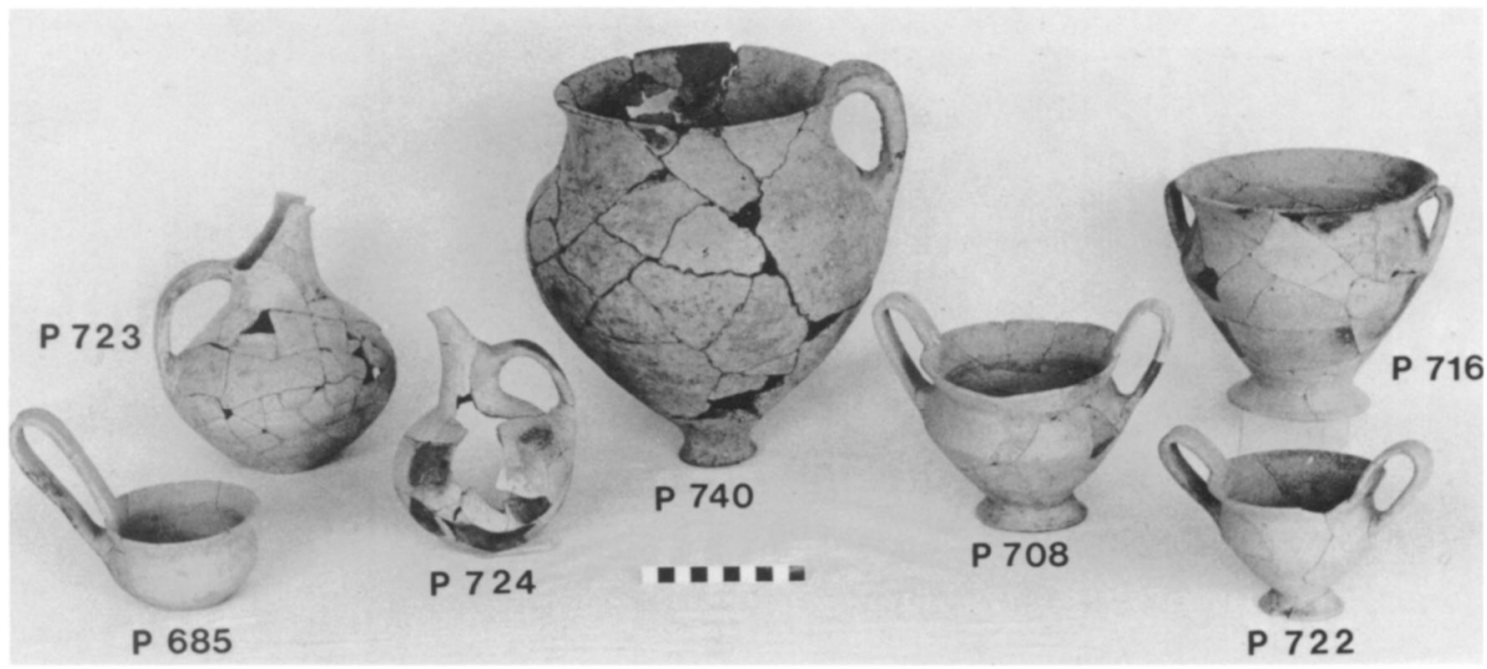

a. Restored vessels from floor deposit

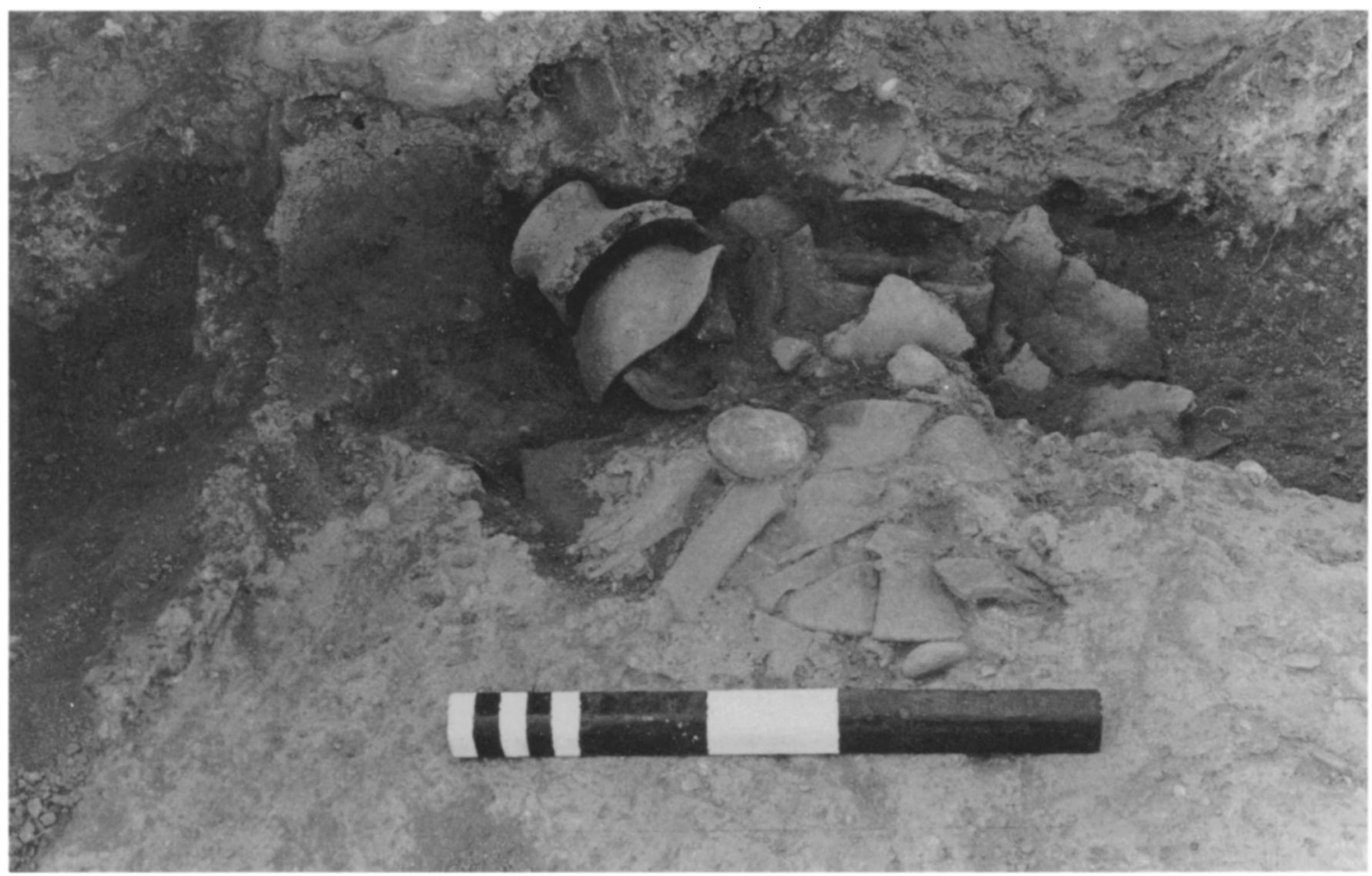

b. Ladle (P 685) within base of jar (P 740), from southeast

James C. Wright: Excavations at Tsoungiza (Archaia Nemea), 1981 
PLATE 92

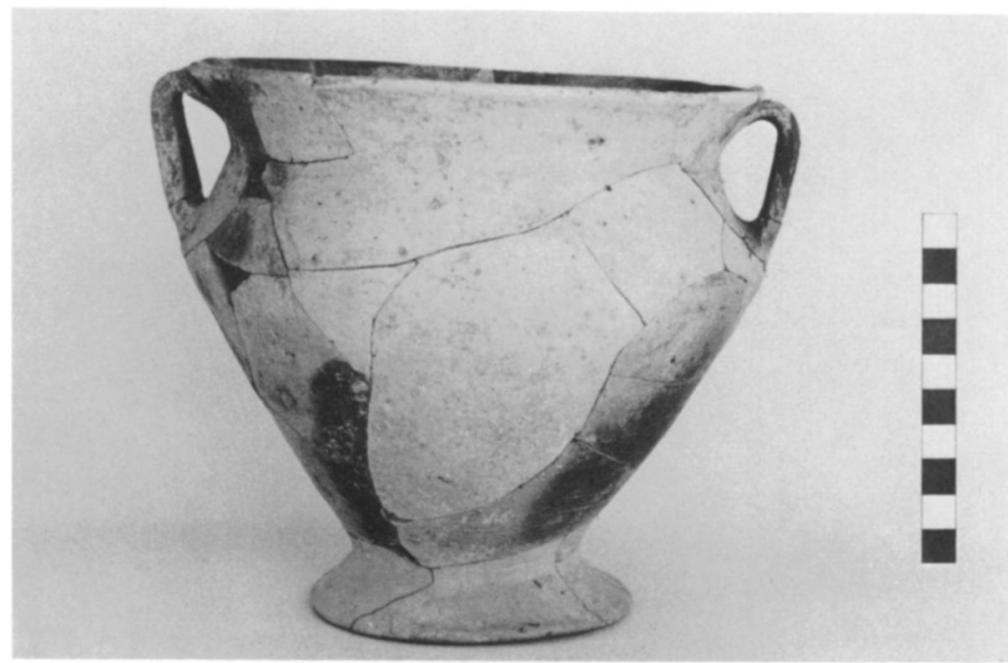

P 716

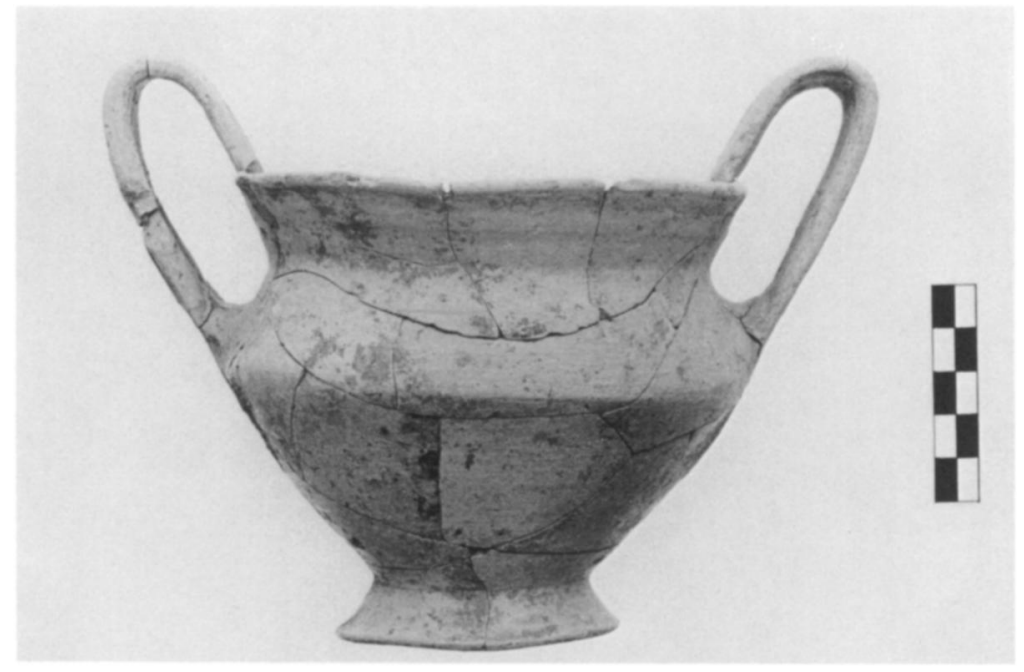

P 708

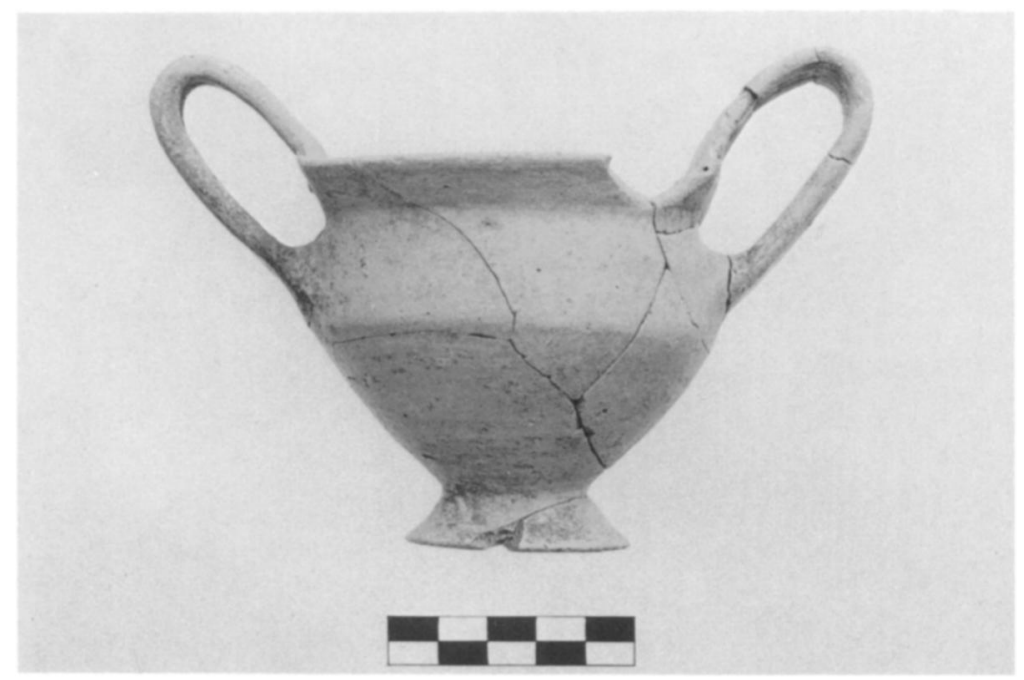

P 722

James C. Wright: Excavations at Tsoungiza (Archaia Nemea), 1981 